\title{
From The Progressives to The Institutionalists: What the First World War Did and Did Not Do to American Economics
}

\author{
Thomas C. Leonard
}

Review essay on Rutherford, Malcolm (2011) The Institutionalist Movement in American Economics, 1918-1947: Science and Social Control, Cambridge University Press, Cambridge, UK, 410 pp. ISBN: 9781107006997 . \$95.

\section{Introduction}

Let me begin by recognizing Malcolm Rutherford's achievement here. In 1998, Geoffrey Hodgson, writing in the Journal of Economic Literature, could say that we lacked an adequate history of Institutionalist Economics. No longer. Thanks to Rutherford's long labors in the archives, begun before the $21^{\text {st }}$ century was, we now have a splendid history of Institutionalist Economics, and more generally, of the Institutionalist movement, and of American economics between the wars. This is a meticulous, carefully crafted, brick by brick reconstruction of an important but misunderstood era in economic and social thought. At its very best moments, you feel like you are peering into a lost world. Rutherford has produced the new standard against which future contributions will be measured, and also to which historians of American economics will be obliged to respond. Our charge in this symposium is to respond.

\section{What the book does}

The structure of the book is straightforward: we are introduced to the founding group and its students, and we are given compelling portraits of some neglected but important figures, Walton Hamilton and Morris Copeland, who stand in for the first and second generations, respectively. Next we proceed to the core of the book, the professional milieu of the Institutionalist economists, the "personal, institutional, and programmatic bases" of the movement in the Institutionalist academic strongholds - Chicago, Wisconsin, Columbia, Amherst, Brookings, and the National Bureau. Lastly, we get an account of the decline of Institutionalism in the late 1930s and early to mid-1940s. Institutionalist economics was undone, Rutherford argues, by the failure of movement economists to reproduce themselves (partly caused by migration to law schools and other disciplines), by the Keynesian revolution's successful co-opting of the under-consumption hypothesis, and by the formalist turn of WWII American economics, hastened by the arrival of mathematically oriented European intellectuals 
fleeing Nazi Germany, and by European philosophies of science that reconceived what it meant to be scientific in the sciences of society.

It is one of the great strengths of the book that we get filiations of ideas and issues carefully situated in their social and personal contexts. Rutherford is not content to understand only what the Institutionalists wrote; his is a fine-grained reconstruction of the professional networks that they built, and in which they wrote, taught, advised, hired, feuded and lobbied. Rutherford has chosen to call Institutionalism a movement and this requires establishing a selfconscious unity of people, of ideas, and of program. I find the book's evidence on this score persuasive.

Almost in passing, Rutherford debunks various myths of Institutionalist economics, which, have together served as a kind of standard narrative. The myths are: one, that Institutionalist economics merely dissented to orthodoxy rather than make positive contributions; two, that Institutionalist economics was best represented even personified by Thorstein Veblen; and three, that IE was unscientific, no more than a compilation of economic facts awaiting a theory or, as Ronald Coase put it, a fire. Rutherford had already challenged these canards in earlier work that the book gathers together, but the force of a full history puts them to rest.

Institutionalism was far more than mere dissent to orthodoxy; it attracted some of the best minds in American economics between the wars and built a network of scholars who were wellestablished and well-funded at leading universities - Chicago, Wisconsin and Columbia, as well as research institutes, such as Brookings and Wesley Clair Mitchell's National Bureau of Economic Research. When Institutionalists did quarrel with orthodox economics, they most often did so from a position of intellectual and institutional strength. Indeed, the orthodoxy they critiqued was not obviously a mainstream: American economics in the 1920s and 1930s was decidedly plural, with permeable and fluid intellectual boundaries (Morgan and Rutherford 1998). Institutionalist work on theory of the firm, and Institutionalist criticisms of untestable theory, for example, clearly influenced orthodox economics.

The second myth reads Institutional economics as Veblenism. Rutherford acknowledges Veblen's influence, but, in his telling, even if Veblen fathered Institutional economics, Veblen did not raise it. Veblen, after all, was 61 years old when Walton Hamilton published his manifesto. Institutional economics was named, raised and shaped by others, notably Walton 
Hamilton and John R. Commons, who did the hard work of parenting - crafting methodologies, setting research agendas, securing funding, building institutions, and forming alliances.

The third myth makes Institutionalist economics unscientific. The book's terminal date is 1947, the year in which Tjalling Koopmans disparaged Institutionalism as mere measurement without theory. There was, it can be acknowledged, some merit in Koopmans' charge. The impetus to provide a more realistic picture of human action was a key aspect of the appeal of Institutionalist economics, but its promise to provide psychological foundations to economics was a promise that remained unfulfilled (p. 352). Rutherford acknowledges that Institutionalism's psychological foundations remained in a "vague and undeveloped state," a deficit that contributed, moreover, to the ad hoc rather than systematic character of Institutionalist theory (ibid).

Theory, however, is no more sufficient for science than is measurement, and, granted its own Pragmatism-informed conception of science, Institutionalist economics was scientific. Indeed Institutional economics began life with a critique of orthodox economics as too speculative and deductive, and thus unscientific. As John Maurice Clark put it in 1927, "[T]he whole [Institutionalist] movement may be interpreted as a demand for a procedure which appears more adequately scientific." One might almost, Clark said, "make [Institutionalism] coextensive with the scientific point of view - in economic study," where the scientific point of view meant "studying the interrelations of business and other social institutions as they are and not through the medium of any simplified abstractions such as are employed by classical, static, and marginal economics" (Clark 1927: 221, 271). A properly scientific economics, Institutionalists argued, was an empirical and investigational (not necessarily quantitative) economics. ${ }^{1}$

But what counts as science in the sciences of society can change, as it did in the twenty years between Clark and Koopmans. The interwar influence of logical positivism and logical empiricism, imported by European intellectuals mostly unacquainted with American Pragmatism, gave aid and comfort to what Koopmans called theory - hypothetico-deductive method joined to formal methods and ethos imported from applied mathematics.

${ }^{1}$ Economics, Clark said, "must come into closer touch with facts and embrace broader ranges of data than "orthodox" economics has hitherto done. It must establish touch with these data, either by becoming more inductive, or by much verification of results, or by taking over the accredited results of specialists in other fields, notably psychology, anthropology, jurisprudence and history" (Clark 1927, p. 221). 


\section{Origins of Institutionalism in progressive economics}

I wanted more from the book on the origins of Institutionalism. That's not a criticism, which would be churlish, for all books must start somewhere, and Rutherford quite plausibly starts in 1918. But Institutional economics had deep connections to the people, ideas and programs of Progressive Era economics, the American political economy of the roughly three decades to 1918. After all, the leading economists traditionally identified with Institutionalism came of age and made their reputations in the Progressive Era. The first generation of American progressives was born between the mid-1850s and 1870. This cohort included Commons and Veblen. In 1918, Commons was 56 years old; Veblen was 61. Even Mitchell, who, born in 1874 , just missed being of the original progressive generation, was already 44 in $1918 .{ }^{2}$

But standard historiography locates a profound discontinuity in 1918; it says, moreover, that American progressivism died with WWI. This narrative has tended to distance the Institutionalists from the progressives; interwar American economics, the conventional narrative seems to suggest, arose ex nihilo from the wreckage of the Great War. But progressive economics did not expire in 1918, and neither did its creators. Progressive economics and Institutional economics shared key figures, ideas and programs. It is no accident that many of the key nodes in Rutherford's Institutionalist network, notably Columbia and Wisconsin (and we might add Michigan), were already progressive strongholds. It is better to say that progressive economics reconstituted in the aftermath of a global calamity.

What follows is a very preliminary and necessarily compact attempt to explore some of the continuities and discontinuities between the Progressives and the Institutionalists. It accepts the conventional notion of a rupture caused by the First World War, but, instead of positing the death of progressivism, asks, which aspects of Progressive Era reform economics survived the war, to be continued or reconstituted by Institutional economics, and which did not?

$* * * * *$

Rutherford is unafraid of clear synthesis and he concludes the book with a definition of institutionalism. So what was it? First, Institutionalism made institutions and institutional change analytically central: institutions constrain behavior and also shape beliefs and values and 
preferences. ${ }^{3}$ Second, Institutionalism rejected utility maximization and its sometimes adjunct, hedonistic psychology, in favor of a social psychology. Third, Institutionalism thought economics should be more scientific which, recall, meant an empirical and investigational (not necessarily quantitative) approach. Fourth, Institutionalism embraced the need for more and better forms of social control, that is, greater government regulation of the market and other interventions - what Walton Hamilton called "the continual guidance of social and industrial development.” Fifth, Institutionalism rejected standard economic theories of value and efficiency, in favor of a more pragmatic and humanistic approach, mostly borrowed from John Dewey (p. 347).

Rutherford's summary strikes me as not so different from an earlier reform manifesto, progressive economist Richard T. Ely's first version of the AEA statement of principles, which declared the "doctrine of laissez faire [to be] unsafe in politics and unsound in morals," celebrated the state as an "agency whose positive assistance is one of the indispensable conditions of human progress," called upon church, state and science to jointly resolve the labor question, and dismissed orthodox political economy as so much speculation, which he then pointedly distinguished from the more scientific methods of progressive economics, "the historical and statistical study of the actual conditions of economic life" (in Seligman 1925, pp. 148-49). These two creeds - progressive and Institutional - are similar, only the addition of institutions is fundamental.

Rutherford says the Institutionalists regarded themselves as part of the reform economics tradition pioneered by the progressive economists, only more modern, more scientific, and more up to date. Yes, but let us be more specific. 1918 usefully marks the decline of three key intellectual touchstones for American economics: the social Gospel, Darwinism, and the idealized state. But the key progressive doctrine, social control, not only survived but flourished in the War's aftermath, as did the progressives' deep and abiding faith in the moral and epistemic authority of science.

\footnotetext{
${ }^{3}$ Institution is one of the more ambiguous terms in political economy. Sometimes it is seen as a habit or behavior influenced by formal rules (laws) or informal rules (social norms and conventions). Other times it's the rule itself. Still other times an institution is an organization, such as a firm, a university, or a bureau. So institutions can be the rules of the game, the established play of the game, and or the players in the game.
} 


\section{Decline of the Social Gospel ${ }^{4}$}

The Social Gospel, which deeply informed American progressive economics, describes a late $19^{\text {th }}$-century and early $20^{\text {th }}$-century form of evangelical Protestantism that sought progressive economic and social improvement via a religiously motivated and scientifically informed project of social redemption. The Social Gospel went into decline after World War I. Partly this was because the slaughter and animal irrationality of the Great War gave the lie to the progressive idea of spiritual and social progress via enlightened social control. But the Social Gospel also suffered from earlier developments internal to American social science. By the outbreak of the war in Europe in 1914, American economics had become an expert, scientific discipline, having establishing a beachhead in the universities by 1900, and in government soon thereafter. Between 1900 and 1914, the imperatives of professionalization pushed progressives toward the view that scientific credibility required an economics free of the pieties of the Social Gospelers; in Mary Furner's (1975) formulation, objectivity required foreswearing advocacy.

Professional economics' turn away from the language and imagery of social Christianity was not solely a matter of vocational calculation. Reform economics recast its Christian idealism in a more secular form also in recognition of the increasing diversity of American progressivism, which made the Social Gospel vision of a Protestant commonwealth too sectarian. Catholics, Jews and others, millions of whom had arrived upon US shores between 1890 and 1914, could and did entertain rather different views of what religious ethics demanded of the state. It didn't help that, in the early 1920s, conservative fundamentalists attacked the evolutionary science the Social Gospelers found so congenial, offering intellectuals a quite different image of American Protestantism.

When Social Gospelers recast their evangelical rhetoric in more secular terms, they turned to the language of science. Simon Patten's (1911:v) effort to place religion on a more scientific basis, The Social Basis of Religion, he described as transferring Christian doctrines from "the traditional basis to the realm of social science." Patten's former student and Wharton School colleague, Scott Nearing (1916) went further still; his Social Religion: An Interpretation of Christianity in Terms of Modern Life dispensed with theology and the other elements of established church practice, and essentially made Christianity coextensive with progressive reform.

\footnotetext{
${ }^{4}$ This section borrows from Leonard 2011.
} 
When Ely, Commons, Patten and the other Social Gospel economists, like all progressives, secularized their Christian idiom, they did not abandon the religious idealism driving their reform impulse. Instead, they reconstituted it, making the social Gospel into what historian David Hollinger has called the "intellectual gospel" (1989: 117). The intellectual gospel represented scientific inquiry as itself a kind of religious calling, found religious potential in science, celebrated science in a religious idiom, and believed that "conduct in accord with the ethic of science could be religiously fulfilling" (Hollinger 1989: 123). The progressives' venerated science not merely because they believed scientific knowledge enabled improvement of economy and society, but also because they regarded science as a place where the socially minded could find religious meaning in scientific inquiry's ethos of objectivity, self-denial, pursuit of truth, and service to a cause greater than oneself.

The end of the First World War usefully marks the end of the Social Gospel in American economics, and indeed of any significant religious influence in American economics. The Institutionalists did, however, carry forward a form of the progressives' "intellectual gospel," one that moved away from the religious significance progressives found therein, but continued to venerate science. The First World War did not discredit science, or its virtues for economics, as can be seen in the scientistic rhetoric of John Maurice Clark and other Institutionalists.

\section{The decline of Darwinism's outsized influence upon American economics}

Darwinism was the master metaphor of the Progressive Era, enough that it is difficult to over-estimate the influence of evolutionary thinking upon Progressive Era social scientists. ${ }^{5}$ Thorstein Veblen (1899) proposed that economics be reconstructed upon Darwinist principles. ${ }^{6}$ John Dewey (1909) claimed Darwin for his version of pragmatism. The progressive economists were no less influenced by the vogue for Darwinian explanation in social science. Richard T. Ely's (1903) Studies in the Evolution of Industrial Society attempted an evolutionary synthesis that would explain the evolution of society, economy and humankind. Simon Patten's Theory of Social Forces (1896) and his Heredity and Social Progress (1903) were, among other efforts, Patten's attempt to found his sui generis political economy upon an evolutionary scientific foundation. John R. Commons' Races and Immigrants (1907) volume depicted African

\footnotetext{
${ }^{5}$ The idea of Darwinism as "master metaphor" I owe to Bellomy (1987).

${ }^{6}$ See Rutherford (1998) on Veblen's Darwinian program.
} 
Americans as irredeemably inferior biologically, and also made a case against immigration on grounds of racial inferiority. All of these progressive projects we may speak of as reform Darwinism.

The extraordinary Darwinian vogue in American social science begins to wane, if only gradually, in the 1920s - Darwinism went from master metaphor to mere influence. The causes of Darwinism's decline in influence are several, but one important factor was the belated success of eugenicists in ending immigration from Asia and from southern and eastern Europe. Already stalled by World War I restrictions, the immigration of the eastern and southern European peoples eugenicists deemed racially inferior was effectively terminated by eugenics-inspired immigration restrictions, notably the Emergency Quota Act of 1921 and the Immigration Act of 1924. The Immigration Act's quotas reduced by $97 \%$ immigration from southern and eastern Europe, which had averaged 730,000 per year in the decade before World War I (1905-1914), to a mere 20,000 per year (Leonard 2005). It ended Japanese immigration altogether.

Evolutionary concepts retained currency in Institutional economics, but the Institutionalists gradually moved away from the progressive economists' emphasis on heredity, selection, fitness and race, using "evolution" to denote the historical and cultural contingency of economic processes.

\section{Decline of the idealization of the state as social organism}

When Walton Hamilton presented his Institutionalist manifesto in December of 1918, Armistice Day (November $11^{\text {th }}$ ) had only just ended hostilities, and the appalling wreckage of World War I was already in view. Irving Fisher's Presidential address to the AEA ("Economists in Public Service"), given at the same meeting where Hamilton unveiled his manifesto, spoke to the perils of economic expertise, when he darkly referred to the German political economists as prostitutes of a criminal regime. "We received from Germany the idea . . of making economics of service to "the state," said Fisher. But, he continued, "the war's revelations have made us realize, to our horror, that 'the state' served by the German economists . . was simply the Hohenzollern dynasty. We now know that German professors . . . have prostituted their professional services to serve Germany's criminal purposes” (Fisher 1919: 7).

American progressive economists admired and advocated the "German model" they were exposed to as graduate students, and they had, moreover, given little thought to the risk that the state might become something other than the organic embodiment of an enlightened people's 
collective mind. The progressives' belief in an organic state, and its goodness, were dealt severe blows by the First World War. It was, in December 1918, impossible to continue to endorse German-inspired notions of the American state qua social organism.

But American economics did not abandon the idea of economic expertise in the service of the state, what the progressives called social control. To the contrary: Institutionalist economists moved away from the progressives' organicist conception of the state, but they nonetheless advocated more and better social control. Irving Fisher discredited experts who served criminal states, but he did not reject the core progressive belief in the state as an active agency of civilization and improvement. For Fisher, as for Walton Hamilton, the chief lesson of the war with respect to social control was not professional humility but professional opportunity. Fisher, no less than Hamilton (albeit with different methodological premises), used the occasion of his address to promote a whole host of new economic reforms. Social control was a catchphrase of Progressive Era economics, and it survived the war, indeed was invigorated by it.

\section{The First World War as a positive benefit to social control ${ }^{7}$}

How was it that the First World War, which so discredited the progressive economists' belief in an organic state and the idea, more generally, of social progress via enlightened government, benefitted social control in American reform economics? I would instance two broad reasons: first, the war solidified and expanded the nascent American regulatory state, and second, the war gave economists an unprecedented opportunity to implement their ideas about economic planning in the cause of war mobilization, both of which expanded and legitimized the role of economic expertise in government service.

By the outbreak of war in Europe in 1914, progressive economics had already made important strides in the establishment of a regulatory state. The U.S. government had created the Federal Reserve banking system, amended the Constitution to institute a graduated personal income tax, established the Federal Trade Commission, applied anti-trust laws to industrial combinations, exempted labor unions from anti-trust prosecution, restricted immigration, regulated food and drug safety, conserved federal lands, established a Children's Bureau, supervised railroad rates, and outlawed railroad price discrimination.

State governments regulated working conditions, inspected factories, banned child labor, compelled education for children, mandated workmen's compensation, instituted "mothers'

\footnotetext{
${ }^{7}$ This section borrows from Leonard 2009.
} 
pensions" (payments to single mothers with dependent children), capped working hours, set minimum wages, taxed inheritances, adopted antitrust statutes, and banned corporate donations to political campaigns.

Economic progressives were instrumental in effecting nearly all these Progressive Era reforms, and they also, increasingly, advised or staffed the government bureaus created by the legislation they promoted (and sometimes even drafted). The growing government demand for economic expertise in the early $20^{\text {th }}$ century, moreover, reinforced the institutional status of the university as the incubator and supplier of economic expertise (Porter 2003: 39). By 1915, the training of scientific experts for public service was deemed a university function fully co-equal with the traditional goals of advancing knowledge and instructing students. ${ }^{8}$ Before American entry into the war, then, there was a social control infrastructure, in the universities and in the government bureaus, blueprinted and built by the progressive economists and their reform allies. It was still rudimentary, more foundations than an entire edifice, but the Institutionalist generation of economists had access to professorial chairs and the seats in government commissions and bureaus.

American entry into the war bolstered the social control infrastructure, by expanding and fortifying the regulatory state, and, especially, by hiring economists to direct economic planning for war mobilization. Large wartime expenditures and decreased tariff revenues from the wartime decline in international trade gave rise to the Revenue Act of 1917, a crucial watershed in the development of the regulatory state (Brownlee 1990). The Revenue Act raised federal income tax rates, steeply increased income-tax progressivity (its top rate was 63\%), expanded the income tax base, and taxed estates along with excessive war profits (ibid). Though American involvement in the war was relatively brief at nineteen months, the Federal government, even after demobilization, remained almost three times its size before the war. ${ }^{9}$

During the war, the U.S. War Industries Board introduced Americans to business planning methods applied by the government to entire economy - it coordinated most

8 "Declaration of Principles on Academic Freedom and Academic Tenure" AAUP Bulletin, vol. I, part 1 (December 1915): 17-39.

${ }^{9}$ In 1914 US government expenditures were \$735 million. In 1922 they were \$3,324 million. Adjusted for inflation (about 58\% 1914-22), US government spending nearly tripled. (US Historical Statistics, Series P 99-108; Series L 1-14). 
government purchasing, determined the allocation of resources, established priorities in output, restricted the alcohol trade, and fixed prices on commodities in over 60 industries (Fogel 2000). During U.S. involvement in World War I, the chief of the Central Bureau of Planning and Statistics of the War Industries Board (WIB) was economist Edwin Gay, dean of Harvard Graduate School of Business Administration. Key Institutionalist economists like Mitchell were drafted into government service.

Gay and his colleagues seized the opportunity to put their business organizational ideas into government practice (Cuff 1989). When Grosvenor Clarkson, WIB member and historian, called the WIB an "industrial dictatorship," he exaggerated, but for the purposes of paying a compliment, namely, that the WIB established that "whole productive and distributive machinery of America could be directed successfully from Washington (in McGerr 2003: 287, 285). The war planning effort, in Clarkson's characterization, was "a story of the conversion of one hundred million combatively individualistic people into a vast cooperative effort in which the good of the unit was sacrificed to the good of the whole ...." In appraising the advantages mobilization provided to the reform movement, Clarkson volunteered that they "almost [make] war appear a blessing instead of a curse" (in McGerr 2003: 299). ${ }^{10}$

The WIB's success at war mobilization affirmed the progressive faith in expertise, and provided credibility for their view that business-planning methods could be applied by the government to the economy at large. John Dewey, for example, believed that war collectivism provided the most important American lesson of the First World War: Washington planners could direct a vast economy. The success of wartime economic planning, Dewey said, was an intellectual "revolution," impossible to ignore (Dewey 1929 [1918]: 557). War collectivism also emboldened Veblen (1921), who conceived of the U.S. economy as a single, giant firm, governed by a soviet of central-planning engineers - not state ownership exactly, but a kind of planners' trusteeship. The war was a boon for economic planning, and, thereby, for the enterprise of American social control more generally.

\section{Conclusion}

Progressives like Ely, Commons and Edward A. Ross had baldly characterized experts as superior men who could, by dint of not just their superior training but also their superior virtue, interpret the "collective mind of society" and act in its best interests. This heroic, elitist self-

\footnotetext{
${ }^{10}$ My discussion of the WIB is indebted McGerr 2003, especially pp. 283-299.
} 
conception of the economic expert, like the German-inflected view of the state as a social organism, waned after the war. Institutionalists generally eschewed the progressives' elitism; the progressive expert was necessary to identify the social good, whereas the Institutionalist expert merely served the social good. Still, the progressives' extravagant faith in expert social science the necessary condition for the vaulting ambition of social control - clearly survived the war and flourished, albeit in this more technocratic vein.

My account here of the Progressive Era origins of science and social control in American Institutionalist economics is, I hope, while necessarily preliminary, worthy of further development. It is but one of many lines of inquiry that have been and will be stimulated by Rutherford's exemplary history. 


\section{References}

Bellomy, Donald C. 1987. "Two Generations: Modernists and Progressives, 1870-1920" Perspectives in American History, New series, Volume 3, pp. 269- 306.

Brownlee, Elliot. 1990. "Economists and the Formation of the Modern Tax System in the United States: The World War I Crisis." In The State and Economic Knowledge: The American and British Experiences, edited by Mary O. Furner and Barry E. Supple. Cambridge: Cambridge University Press.

Clark, John Maurice (1927) "Recent Developments in Economics" in Edward C. Hayes (ed.), Recent Developments in the Social Sciences. Philadelphia: Lippencott, pp. 213-306.

Cuff, Robert (1989) “Creating Control Systems: Edwin F. Gay and the Central Bureau of Planning and Statistics, 1917-19.” Business History Review 63: 588-613.

Dewey, John. 1929 [1918]. "The Social Possibilities of War” Reprinted in Characters and Events: Popular Essays in Social And Political Philosophy, Volume 2. Joseph Reder, ed. New York: Henry Holt, pp. 551-560.

Ely, Richard T. (1903) Studies in the Evolution of Industrial Society. New York: Macmillan.

Fisher, Irving (1919) "Economists in Public Service" The American Economic Review 9(1): 521.

Fogel, Robert. (2000) “Academic Economics and the Triumph of the Welfare State." AAU Centennial Meeting, Washington, D.C.

Furner, Mary. 1975. Advocacy and Objectivity: A Crisis in the Professionalization of American Social Science 1865-1905. Lexington, KY: University Press of Kentucky.

Hodgson, Geoffrey M. (1998) “The Approach of Institutional Economics.” Journal of Economic Literature 36(1): 166-192.

Hollinger, David (1989) “Justification by Verification: The Scientific Challenge to the Moral Authority of Christianity in Modern America", in Religion and Twentieth-Century American Intellectual Life, Michael J. Lacey, ed., pp. 123-135.

Leonard, Thomas C. (2011) "Religion and Evolution in Progressive Era Political Economy: Adversaries or Allies?” History of Political Economy 43(3)

Leonard, Thomas C. (2009) "American Economic Reform in the Progressive Era: Its Foundational Beliefs and Their Relation to Eugenics" History of Political Economy 41(1): 109-141. 
Leonard, Thomas C. (2005) "Retrospectives: Eugenics and Economics in the Progressive Era." Journal of Economic Perspectives 19(4): 207-224.

McGerr, Michael. (2003) A Fierce Discontent: The Rise and Fall of the Progressive Movement in America, 1870-1920. New York: Free Press.

Morgan, Mary and Malcolm Rutherford, eds. (1998) From Interwar Pluralism to Postwar Neoclassicism. Supplement to Vol. 30 of History of Political Economy. Durham, N.C.: Duke University Press.

Nearing, Scott (1916) Social Religion: An Interpretation of Christianity in Terms of Modern Life New York: Macmillan.

Patten, Simon (1911) The Social Basis of Religion. New York: Macmillan.

Patten, Simon (1903) Heredity and Social Progress. New York: Macmillan.

Patten, Simon (1896) The Theory of Social Forces. Philadelphia: American Academy of Political and Social Sciences.

Porter, Theodore (2003) "Genres and Objects of Social Inquiry, from The Enlightenment to 1890." In Theodore Porter and Dorothy Ross (eds.) The Cambridge History of Science: The Modern Social Sciences, Cambridge, UK, pp. 13-39.

Rutherford, Malcolm (1998) Veblen's Evolutionary Programme: A Promise Unfulfilled. Cambridge Journal of Economics 22: 463-77.

Seligman, E. R. A. (1925) “Economists.” In Essays in Economics. New York: Macmillan.

Veblen, Thorstein (1921) The Engineers and the Price System. New York: B.W. Huebsch.

Veblen, Thorstein (1899). The Theory of the Leisure Class: An Economic Study in the Evolution of Institutions. New York: Macmillan. 